\title{
THE FACTORS OF INITIAL RETURN RELATED TO IPO COMPANIES ON THE INDONESIA STOCK EXCHANGE
}

\author{
Glynae Widyawati ${ }^{1}$, Bambang Juanda ${ }^{2}$, Trias Andati ${ }^{3}$ \\ ${ }^{1,3}$ Management and Business, Business School, IPB University, 16218 \\ ${ }^{2}$ Economics, Faculty of Economics and Management, IPB University, 16680 \\ *Corresponding author: widyawatiglynae@gmail.com
}

\begin{abstract}
Companies that conduct IPOs will increase company's value with an optimal capital structure. Initial return is a profit that investors can obtain from the initial share price is lower than the opening price of the secondary shares on the first day. Underpricing conditions occurs because the initial stock price is lower than the secondary stock price on the first day. This study aimed to analyze factors that impact initial returns on companies that conduct IPOs on the Indonesia Stock Exchange, analyze the effects of financial factors (ROE, DER, and BI Rate) and non-financial factors (professional auditors and underwriters) on initial returns to companies conducting IPOs in IDX, and how the behavior of investors towards those analysis. The linear regression data processing using SPSS 16 produced result that only the BI Rate variable which affected the initial return on the seven days, 30 days, and one year after the IPO observation period. The statistical results show the best $r$-square value is 17.6 percent, which means that the independent variables can be used to explain the effect to the initial return on 17.6 percent.
\end{abstract}

Keywords: Financial variables, initial return behavior, investor behavior, non-financial variables, underpricing

\begin{abstract}
Abstrak
Perusahaan yang melakukan IPO bertujuan untuk meningkatkan nilai ekuitas perusahaan sehingga perusahaan memiliki struktur permodalan yang optimal. Initial return merupakan keuntungan yang dapat diperoleh investor akibat harga saham perdana pada saat perusahaan IPO lebih rendah dibandingkan harga penutupan saham sekunder di hari pertama. Kondisi underpricing terjadi akibat harga saham perdana lebih rendah dibandingkan harga saham sekunder di hari pertama. Penelitian ini bertujuan untuk menganalisis faktor-faktor yang memengaruhi initial return pada perusahaan yang melakukan IPO di Bursa Efek Indonesia, meliputi analisis pengaruh faktor keuangan (ROE,DER, dan BI Rate) dan faktor non keuangan (reputasi auditor dan underwriter) terhadap initial return pada perusahaan yang melakukan IPO di BEI, serta bagaimana perilaku investor terhadap analisis-analisis tersebut. Pengolahan data regresi linear menggunakan SPSS 16 menunjukkan hasil bahwa hanya variabel BI Rate yang mempengaruhi initial return secara signifikan pada periode pengamatan tujuh hari, 30 hari, dan satu tahun setelah IPO dilakukan. Hasil statistik menunjukkan nilai rsquare terbaik sebesar $17.6 \%$ yang berarti bahwa variabel bebas yang digunakan dapat menjelaskan pengaruhnya terhadap initial return sebesar $17.6 \%$.
\end{abstract}

Kata kunci: Perilaku initial return, perilaku investor, underpricing, variabel keuangan, variabel non keuangan 


\section{Introduction}

The principle of development is essential for every companies. The companies have done abundant works to defend its company for the long term period and to develop the values of the company and its businesses. In the time of developing the business, company should consider the source of the assets. Nowadays, practicing the initial public offering (IPO) is one of the way in which company attracted to in increasing the source of the public funding from the society, investor, financial institution, and many others. The companies that are practicing the Initial Public Offering (IPO) or mostly known with the term of go public aims to elevate the equity values of the companies therefore the capital structure of the companies optimalized. Based on the data from the Indonesia stock exchange (Figure 1), the total of the companies who involved practicing IPO significantly increase from 2017 as much as 47 percents after tend to decreased in the past few years from 2013-2017. Implementing the company to go public would ease the society and finance institution to get to know the company's financial state through the openness of the information by Indonesia stock exchange or in Bahasa well known as Bursa Efek Indonesia (BEI). The effect of this transparency would simplified the other companies to take loan to the bank and also for the issuance of debt securities. Generally, the tendency of the investor are would invest to the companies who have virtuous image of the financial and non-financial status. The companies who have done the IPO also will own the stock price that being sold to the primary market, which determined based on the deal between issues company and the underwriter, while the price that happening in the secondary market determined by the market mechanism through the demanding and supply force in the capital market.

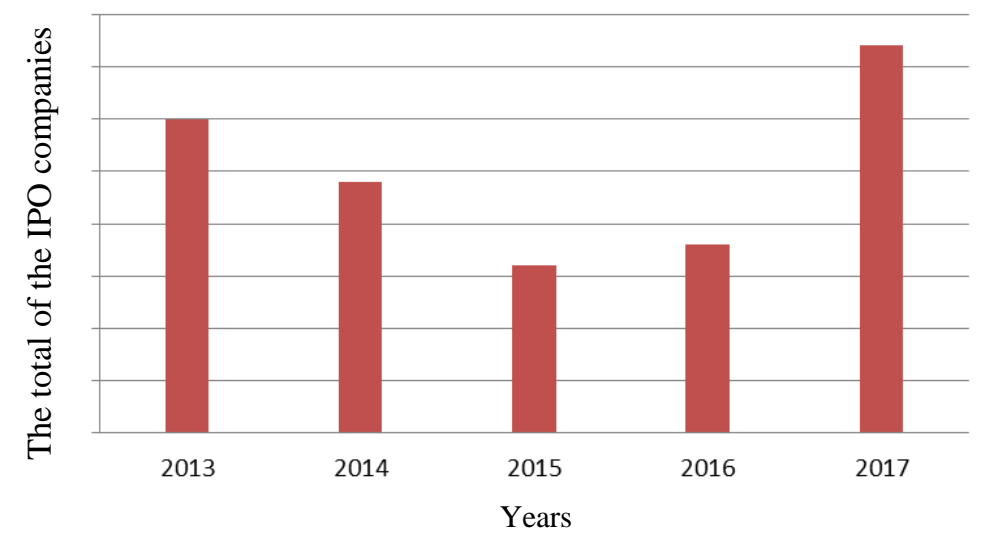

Figure 1 The IPO companies 2013-2017

The initial return is the profit that investors would receive from the first stock price when the IPO companies are lower than the secondary closed stock price on the first day. The initial return measure based on the daily return of the stock price on the first day closing of the secondary market with the stock price on IPO and divide the stock price on IPO (Hartono, 2013). There are three conditions of the stocks after the IPO companies, those are underpricing condition, stable and overpricing. The underpricing condition happens when the initial stock price lower than the secondary stock price on the first day, otherwise when the premier stock price higher than the secondary on the first day, it would be overpricing. The stable state happens when the premier stock price equal with the secondary on the first day. 
Based on Figure 2 it can be seen that the initial rate of return with the underpricing condition in the capital market is quite high. Underpricing conditions explain the initial stock price is lower than the secondary stock price on the first day. In this condition, the company does not get maximum funds when trading on the stock exchange, while in terms of investors will benefit from having shares bought or bought when the initial price is cheaper than the stock price on the secondary market. Figure 2 data shows the number of 2016 to 2017 there was an increase in the number of companies conducting IPOs instead accompanied by an increase in costs in the same period. However, the initial return at the time of the underpricing conditions cannot be ascertained to harm the company and benefit the investor. This is because the underpricing condition can be one of the strategies for both the company or investors to both lead to mutually beneficial conditions thereafter. The company provides a buying incentive for attractive investors by offering a share price at the beginning, while investors are interested in buying shares at a low price early in the hope of an increase in share prices later for resale.

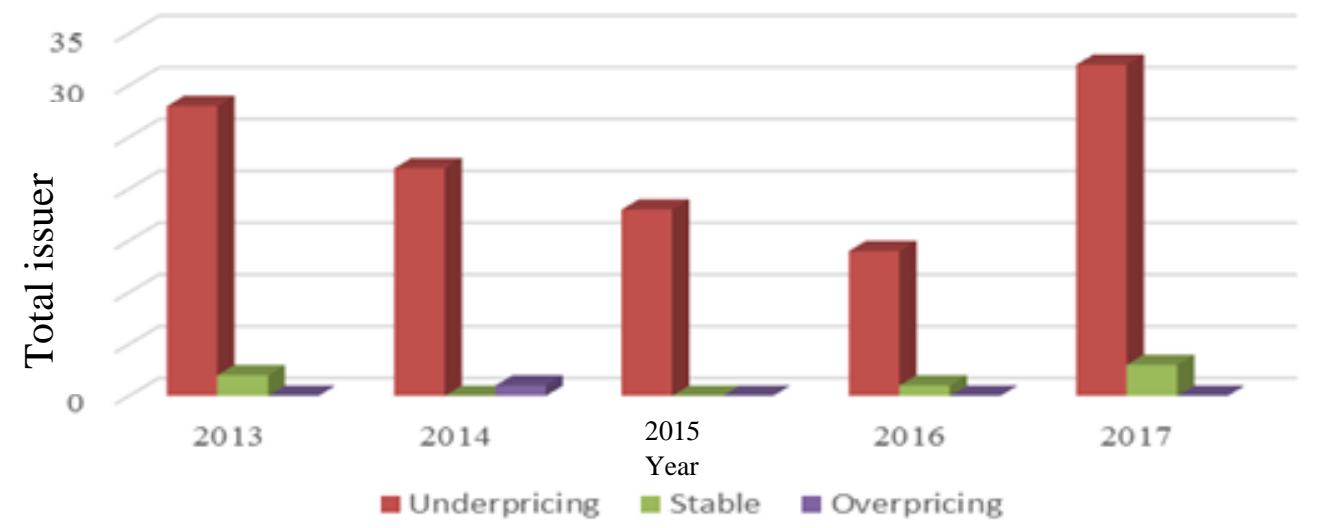

Figure 2 The development of Initial Return in Indonesia 2013-2017

Related to underpricing, Li, Zheng, and Melancon (2005) in their study show that underpricing has a significant effect on company stock liquidity after an IPO and higher liquidity levels for companies that have greater underpricing. This reference indicates that the underpricing condition that makes the issuer not optimally get funds during the IPO encourages increased company liquidity. However, the results of this study cannot yet be justified for all underpricing conditions in every capital market where research conducted by Field and Sheehan (2004) found that underpricing and ownership structure have a weak relationship, and the effect of underpricing on liquidity is still a question. Likewise, in overpricing conditions, where the initial share price is higher than the secondary market share price will benefit the company. Conversely, overpricing conditions will make the investor loss because buying initial shares is more expensive than buying on the secondary market. However, these conditions have not been able to be an accurate benchmark to assess the profit of stock transactions for companies that have just made an IPO. Both companies and investors will continue to make transactions to get the best initial return (IR), both on one day after the IPO, namely one-day initial return or IR1, one-week initial return or IR7, one-month IR30 initial return, and one-year initial return or IR1Y.

Based on this, both the company and investors are equally important to know what factors affect the initial return both underpricing, overpricing, and stable conditions to both achieve a favorable state. These factors can come from internal factors as well as external factors, or financial and non-financial factors. Financial 
factors that can be analyzed by investors and managed by the company include profitability ratios such as ROE (Return on Equity) and leverage ratios such as DER (Debt to Equity Ratio). ROE is the ratio between profit before tax and total equity to measure the rate of return on total investment. This ratio is used to measure the performance of company management in managing available capital to generate profits after tax. Return On Equity is a ratio that shows the extent to which companies manage their capital (net worth) conclusively, measuring the level of profitability of investments made by the owners of their capital or holding company shares (Sawir, 2009). While DER is one of the leverage ratios, leverage is a ratio that measures the extent to which a company's ability to meet its long-term obligations (Hanafi \& Halim, 2000). The higher the leverage, the greater the amount of loan capital used in generating company profits. The leverage has an adverse impact on company performance because the higher the level of debt means reducing the level of profit. Non-financial factors that can be considered by investors include interest rates, auditor reputation, and underwriter reputation. Changes in macroeconomic factors will not immediately affect company performance, but slowly in the long run. Conversely, stock prices will be affected directly by changes in macroeconomic factors because investors react more quickly (Samsul, 2006).

The reaction of an investor to a condition in the stock market is a form of investor behavior and is included in behavioral finance. Pompian (2006) argues that to understand behavioral finance it is necessary to divide into two sub-topics, the first is behavioral finance micro, which is to test the behavior of individual investors or different from rational actors envisioned in classical economic theory. Second, behavioral finance macros that detect and illustrate that behavioral models can explain the occurrence of anomalies (deviations) Efficient Market Hypothesis. Investors who can seize opportunities are investors who learn a lot from the phenomena that occur in the business market. They tend to find out the potential to get high returns based on information on an efficient market.

However, before analyzing the factors that influence initial returns, especially from financial and non-financial factors, it is also important to make observations and examines related to the behavior of initial returns and investors themselves. Initial return behavior can be observed in several periods to see whether there is a consistent pattern so as to provide a comprehensive or specific understanding according to the respective sector of the issuer or company conducting an IPO.

From the company side, the effort to go public should be directly proportional to the profit when doing an IPO where an overpricing condition is expected. While in terms of investors as investment decision-makers, there needs to be a careful analysis. Analysis can only be done if it is supported by the existence of relevant, complete, accurate, and timely information (Usma \& Marzuki, 1990). Investors need to learn a few things before buying a company stock to go public to minimize losses for investors. More than that, investors are also essential to know how the behavior or characteristics of the initial return itself as a reference in making decisions. This research was conducted to analyze the factors that influence the initial performance of companies doing an IPO on the Indonesia Stock Exchange. 


\section{Methods}

This research was conducted for nine months (February 2018 - April 2019). The data used in this study are secondary data obtained from the official website of the IDX and Bank Indonesia as well as several other supporting financial sites that are relevant to the needs of research data. The data in this study include a list of companies conducting an IPO for the 2013-2017 period, interest rates or the BI Rate, company prospectus reports, quarterly or annual company financial reports, annual company reports, list of issuers' stock prices, lists of issuers, and lists auditors included in the Big Four classification. Besides, the name of the underwriter and auditor can be obtained from the annual report, as well as the ranking of the underwriters from Bloomberg statistical data and Big Four KAP affiliates from the IAI directory. The sample selection is chosen using a purposive sampling method based on the following criteria:

1. Conducting an initial public offering (IPO) on the 2013-2017 Indonesian Stock Exchange (IDX).

2. Has an initial price (offering price) at the time of the initial public offering on the Indonesia Stock Exchange in 2013-2017.

3. Having a closing price on the first day traded on the secondary market at companies that made an initial public offering on the Indonesia Stock Exchange in 2013-2017.

4. There is the name of the underwriter (name of the underwriter) and the name of the auditor who audits for a dummy evaluation.

Based on these criteria, the total sample to be examined in this study amounted to 116 companies. The data in this study were processed using the linear regression method with SPSS 16 software. Before the linear regression was performed, a classic assumption test was performed on the variable data used to see whether the data was valid and reliable to be processed. There is numeral research on underpricing conditions which determined the variables that can significantly influence the underpricing or the variables that have no significant influence for the underpricing. Emilia, Lucky Sulaiman, and Roy Sembel (2008) conducted a study entitled "Factors Affecting 1 Day, 1 Month Initial Return, and Influence on Return 1 Year after IPO" and the results show that the two independent variables are reputation variable auditors and earning per share, both variables do not have a significant effect on underpricing either in one day or one month observation period. A similar study was conducted by Junaeni and Rendi (2013) with the title "Analysis of Factors Affecting the Level of Underpricing of Shares in Companies Doing an IPO on the IDX." The result shows that the reputation of underwriters as the independent variable has affected the underpricing variable in a negative and significant direction. Also, the research found that the industry type variable somewhat did not significantly affect the level of underpricing. Research conducted by Risqi and Puji Harto (2013) shows the results that the underwriter reputation, auditor reputation, return on equity, and leverage level variables simultaneously affected the underpricing variable. Ratnasari and Gunasti Hudiwinarsih (2013) in a study entitled "Analysis of the Influence of Financial, Non-Financial Information and Macroeconomic Information on Underpricing in Companies when an IPO," states there are three variables have influenced the underpricing variable. Namely, ROE, KAP Reputation, and Reputation Underwriter. Otherwise, financial leverage (DER) and Inflation Rate, have no significant effect on the underpricing of shares. All of the above studies together use the Multiple Linear Regression Analysis method. This research will also explain the analysis related to the factors that influence the initial return of shares of issuers that conduct an IPO, especially 
on the condition of underpricing. However, this study will also first analyze how the initial return behavior of issuers conducting IPO from 2013 to 2017 or for five years to make a difference with the explanation of some of the previous studies above. So, based on the description of the last research, along with an explanation in the background of the study, the hypothesis used in this study is as follows:

1. H1: ROE has a significant positive effect on the initial return

2. H2: DER has a significant negative impact on the initial return

3. H3: BI Rate has a significant negative effect on the initial return

4. H4: Dummy auditor reputation or DA has a significant positive impact on the initial return

5. H5: Dummy reputation underwriter or DU has a significant positive effect on initial return multiple linear regression model used in this study is as follows:

$\mathrm{IR}_{1}=\mathrm{a}+\mathrm{b}_{1} \mathrm{ROE}+\mathrm{b}_{2}$ DER $+\mathrm{b}_{3}$ BIRATE $+\mathrm{b}_{4} \mathrm{DA}+\mathrm{b}_{5} \mathrm{DU}+\mathrm{e}$
$\mathrm{IR}_{7}=\mathrm{a}+\mathrm{b}_{1} \mathrm{ROE}+\mathrm{b}_{2}$ DER $+\mathrm{b}_{3}$ BIRATE $+\mathrm{b}_{4} \mathrm{DA}+\mathrm{b}_{5} \mathrm{DU}+\mathrm{e}$
$\mathrm{IR}_{30}=\mathrm{a}+\mathrm{b}_{1} \mathrm{ROE}+\mathrm{b}_{2}$ DER $+\mathrm{b}_{3}$ BIRATE $+\mathrm{b}_{4} \mathrm{DA}+\mathrm{b}_{5} \mathrm{DU}+\mathrm{e}$
$\mathrm{IR}_{1 \mathrm{y}}=\mathrm{a}+\mathrm{b}_{1} \mathrm{ROE}+\mathrm{b}_{2} \mathrm{DER}+\mathrm{b}_{3}$ BIRATE $+\mathrm{b}_{4} \mathrm{DA}+\mathrm{b}_{5} \mathrm{DU}+\mathrm{e}$

Note:

$\mathrm{IR}_{1}$

= Initial Return first day after IPO

$\mathrm{IR}_{7}$

$=$ Initial Return day seventh after IPO

$\mathrm{IR}_{30}$

$=$ Initial Return $30^{\text {th }}$ day after IPO

$\mathrm{IR}_{1 \mathrm{y}}$

a

= Initial Return one year after IPO

$b_{i}(i=1,2,3 \ldots d s t)$

$=$ intercept

ROE

= coefficient Slope

= Return on Equity

DER

= Debt to Equity Ratio

BIRATE

$=$ Interest rate Bank Indonesia

DA

= Dummy Auditor

D0: All auditors who are not included in the Big Four Auditor ranking in Indonesia

D1: Auditors included in the rankng of Big Four Auditors in Indonesia

1. PricewaterhouseCoopers (PwC)

2. Deloitte Touche Tohmatsu

3. Ernst \& Young (EY)

4. KPMG.

DU

= Dummy Underwriter

D1: Credit Suisse, PT Mandiri Sekuritas, CITIC Securities Co

Ltd, BNP Paribas, Trimegah Securities

D0: DBS Group, Morgan Stanley, UBS, Bahana Securities, Bank Mandiri

$\mathrm{e}$

$=$ Error 


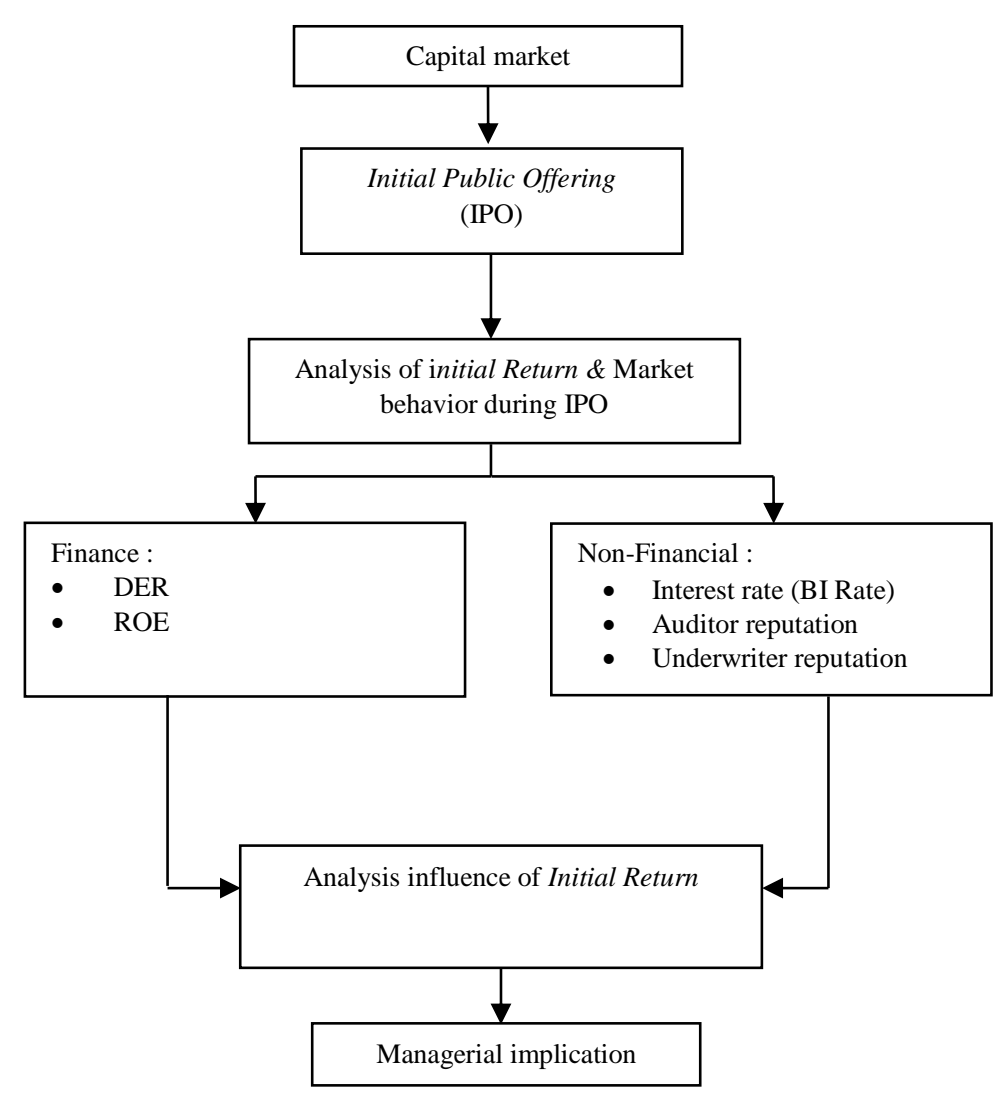

Figure 3 Conceptual research framework

\section{Findings}

\section{Descriptive Statistics}

Descriptive analysis in this study was conducted for two main purpose, namely examine how the behavior of the initial return of each company that conducts an IPO for a period of one day after an IPO (IR1), seven days after an IPO (IR7), 30 days after an IPO (IR30) and one year after IPO (IR1Y) in each 2013-2017 observation year using a bar chart, as well as descriptive analysis to determine the correlation between the independent variables in this study with the dependent variable using a scatter plot diagram. Figure 4 is a bar chart showing the movement of initial returns of issuers conducting IPOs for 2013-2017. The issuers in this study came from nine sectors namely the Consumer Goods Industry sector, the Trade and Investment Services sector, the Various Industry sectors, the Basic \& Chemical Industry sector, the Infrastructure, Utilities \& Transportation sectors, the Mining sector, the Financial sector, the Agriculture sector, the Property sector, Housing and Building Construction, and the Trade, Services and Investment sectors. It appears that there are three years of observation, namely 2014, 2016, and 2017 where the return on stock investment since one year after the IPO (IR1Y) has the highest value compared to the initial return at other times (IR1, IR7, and IR30). Also, there were two years of observation in 2014 and 2017 that showed consistent initial 
return growth where initial returns continued to increase from one day after the IPO to one year after the IPO.

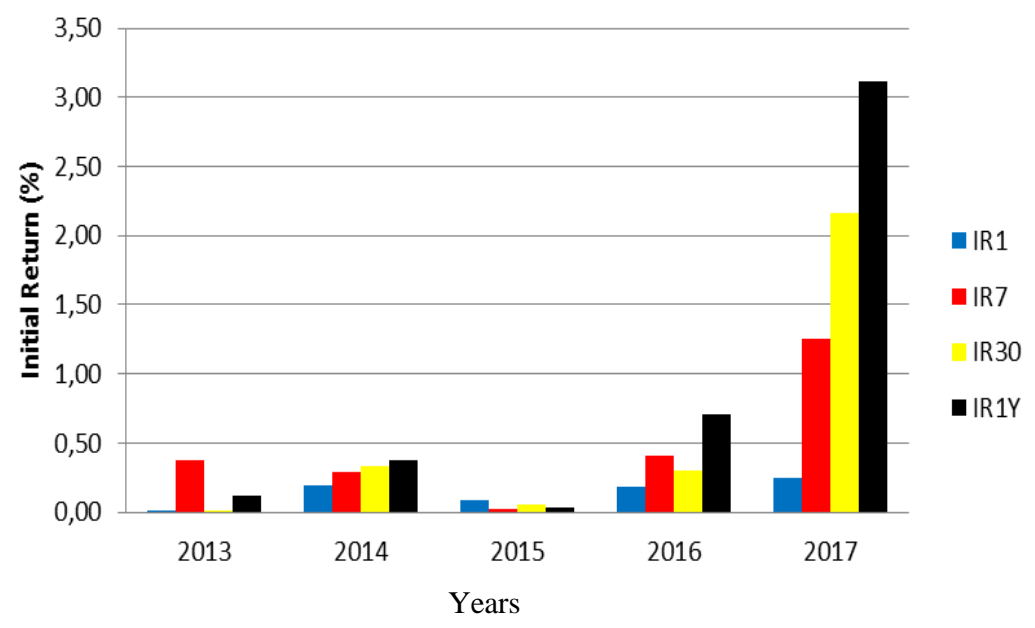

Figure 4 Initial IPO issuer chart 2013-2017

While other observation years in 2013, 2015, and 2016, showed an unstable initial return value at each observation period. The tendency of the initial return value, which is getting better compared to the initial period after the IPO does not occur for all years of observation in this study. This is reasonable because there are other variables that have not been assessed that can contribute to fluctuations in the value of the initial return in each year of observation due to domestic, and macroeconomic economic conditions, as well as the industrial states of each issuer sector every year are different and continue to experience changes.

Ritter and Welch (2002) revealed the concept of signal theory in the phenomenon of underpricing. Underpricing is stated as a mechanism carried out by the company to signal to investors about the quality of the company. So it can be understood that companies that have good quality intentionally underpricing shares so that the company will get the success of the sale of shares during the IPO and the subsequent stock offering. In other words, the issuer deliberately opens a lower stock price or gives a discount to investors, with the hope that opening in the period after the IPO will provide a return that is at least the same and more than the amount of the discount given. The discount price offered during the IPO makes conditions suitable for the signal in the phenomenon of underpricing where not all initial returns on the graphs in Figure 4 increase over time, but tend to fluctuate such as IR30 and IR1Y in 2013, IR7, IR30, IR1Y in 2015, and IR30 in 2016. The author then conducted a descriptive analysis of the initial return intrinsic value data, namely the return value of the opening discount of the stock price at the time of the IPO compared to the closing price in the observation period in this study, namely the first day, seventh day, 30th day, and one day after the IPO. Descriptive analysis shows that the intrinsic value of the share price that reaches a discount return when the Open IPO price is above 25 percents each is 36 percents issuers on the first day, 34 percents issuers on the seventh day, 3.36 percents issuers on the 30th day, and 42 percents on day 1 of the year after the IPO. While the intrinsic value of shares that did not reach the discount return when the IPO opening price was even lower than the opening price (intrinsic value below $0 \%$ ) were 34 percents issuers on the first day, 2.42 percents issuers on the seventh day, 
3.41 percents of issuers on the 30th day, and 57 percents of issuers on the 1st day after the IPO.

The research then analyzes further by examining whether the negative effect occurs on the issuer in the news. Thus it could trigger the initial return, in the period after the IPO declines and the intrinsic value does not reflect a discounted price return. An examination of negative effect on issuers is mainly carried out in the seventh day period after the IPO in order to be able to see the intrinsic value, immediately before the long period after the IPO the intrinsic value will be affected by more factors. From 30 random samples of issuers that examined negative news seven days after the IPO, none of the issuers were reported with negative content or information, but 70 percents of issuers were reported with positive information and the remaining 30 percents were not reported at all during the same period with the year the issuer conducted an IPO. This shows that the intrinsic value in the seventh observation period that did not give a return on the discount value when the IPO was not affected by negative news related to the issuer. Then it is necessary to do further statistical analysis to find out what variables other than negative reporting related to issuers that can affect stock returns.

Companies that conduct IPOs become open to the public regarding the transparency of company performance. The company's performance will reflect the company's achievements, which will later be reflected in the company's stock price. Changes in stock prices are one indication of changes in company performance during a specified period. Company achievement is the company's ability to manage the assets owned and certain resources to generate profits (Azhari, 2016).

Descriptive analysis is then performed to look simply at the statistical analysis of the relationship between the two variables in the study or the correlation between one independent variable and the dependent variable. Scatterplot diagram or scatter diagram serves to see the correlation between one independent variable and the dependent variable. Processing the two related variable data will produce a scatterplot image that can be determined how the conditions of the diagram results. The Y-axis in the scatterplot diagram in this study is the axis for the dependent variable or variable to be predicted, namely the initial return (IR) while the X-axis in the scatterplot diagram in this study is the axis for each independent variable which includes financial variables namely ROE, DER, BI Rate (in data processing labeled BIRATE) and non-financial variables namely dummy auditor (DA) and dummy underwriter (DU).

Scatterplot diagrams were also performed for descriptive analysis in looking at the correlation between each independent and dependent variable in this study. In the scatterplot diagram results, Table 1 shows the same descriptive statistical results, namely a negative correlation between the BI Rate and the initial return on the seventh day (IR7), the initial return on the 30th day (IR30), and the initial return on one year ( IR1Y). While there is no correlation at all between the dummy auditor variable with the dependent variable initial return for the four observation periods. The starting BI rate appears to have a negative correlation with the initial return generated on the seventh day after the company conducts an IPO for one year after the IPO. This means that, on the seventh day after the company's shares take the floor on the stock exchange, the BI rate condition becomes one of the important variables to consider because it has a negative relationship with the resulting initial return. If the BI rate increases, then the initial return is predicted to move down, and vice versa if the BI rate decreases, then the initial return is predicted to increase. 
From the results of this descriptive analysis it is known that when conducting an IPO, the acquisition of initial return on the first day was not influenced by either the financial or non-financial factors used in this study. While the BI Rate is only the only variable that affects the initial return on the seventh day, 30th day, and one year. This means, the other financial variables in this study are ROE and DER, the Auditor's reputation and the underwriter's reputation do not affect the initial return.

Table 1 Scatterplot diagram correlation between BI rate or dummy auditors with initial return variables for each observation period

\begin{tabular}{ccc}
\hline Period & BI Rate & Dummy Auditor \\
\hline
\end{tabular}

IR2
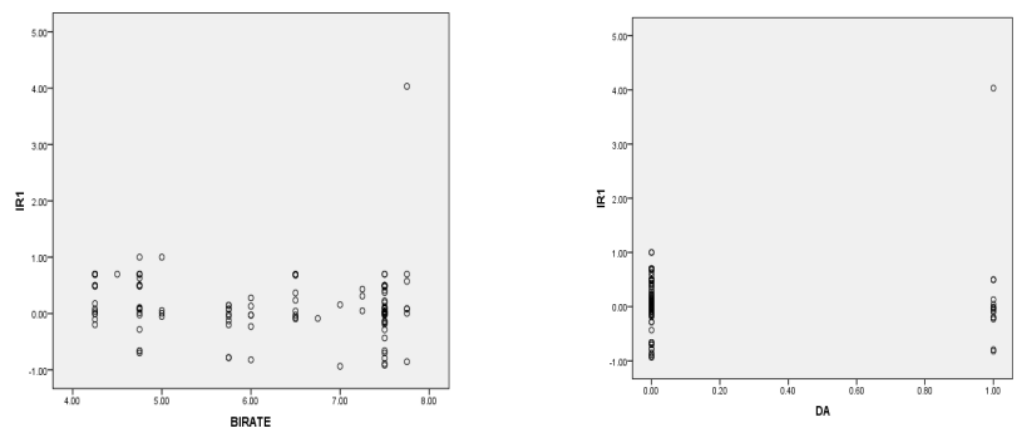

IR1
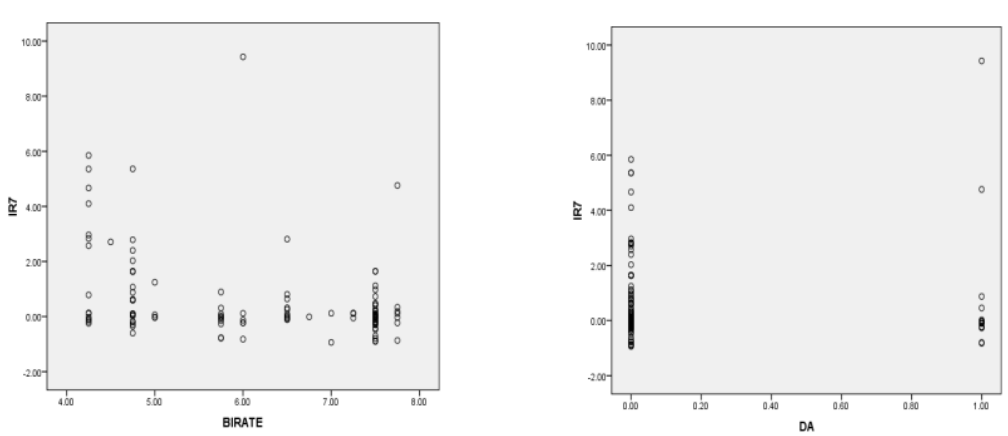

IR30
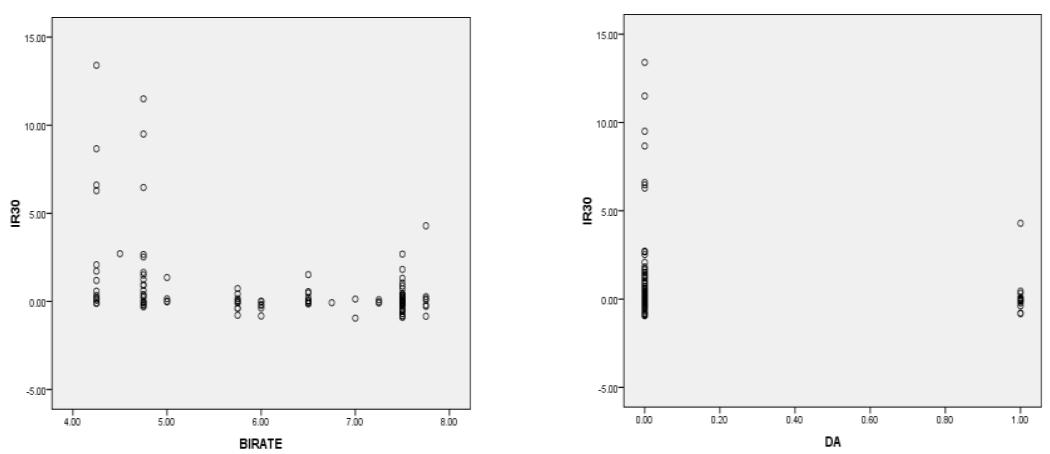
IR1Y
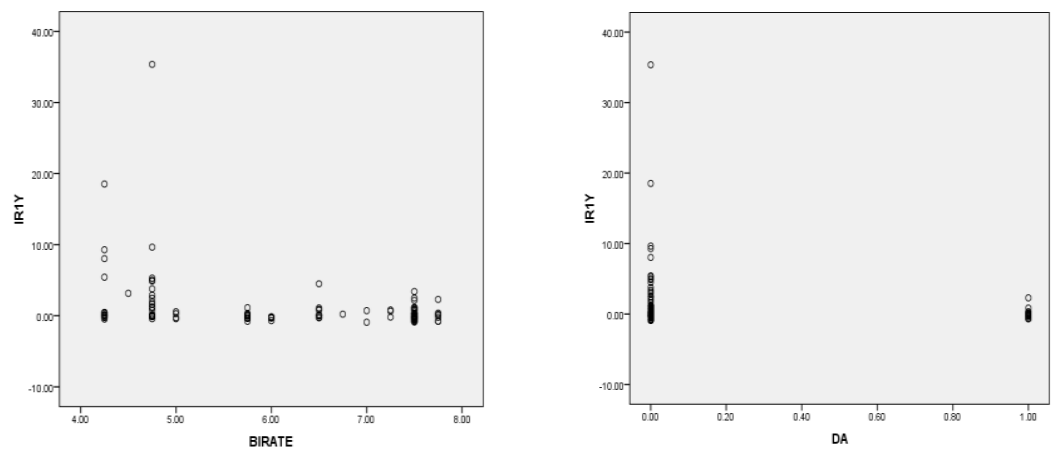

\section{Quantitative Analysis}

Before processing the statistical data following the analysis of statistical results, a classic assumption test applied to all data in this study. The aim was to avoid the statistical problems of classical assumptions that risk-reducing data quality, both in terms of bias or data abnormality. The classic assumption tests include normality test, heteroscedasticity test, multicollinearity test, and autocorrelation test. The classic assumption test in this research is carried out by being represented by the data equation of financial and nonfinancial independent variables with an initial return on the first day after the company conducts an IPO. The results of the classic assumption test using SPSS show that the data used in this study are free from abnormal data distribution issues, heteroscedasticity issues, multicollinearity problems, and autocorrelation problems.

Coefficients $^{\mathrm{s}}$

\begin{tabular}{|c|c|c|c|c|c|c|}
\hline \multirow{2}{*}{\multicolumn{2}{|c|}{ Model }} & \multicolumn{2}{|c|}{ Unstandardized Coefficients } & \multirow{2}{*}{$\begin{array}{c}\begin{array}{c}\text { Standardized } \\
\text { Coefficients }\end{array} \\
\text { Beta }\end{array}$} & \multirow[b]{2}{*}{$t$} & \multirow[b]{2}{*}{ Sig. } \\
\hline & & $\mathrm{B}$ & Std. Error & & & \\
\hline \multirow[t]{6}{*}{1} & (Constant) & .357 & .288 & & 1.240 & .218 \\
\hline & ROE & .000 & .003 & -.022 & -.231 & .818 \\
\hline & DER & .165 & .218 & .072 & .756 & .451 \\
\hline & BIRATE & -.044 & .042 & -.100 & -1.051 & .296 \\
\hline & DA & .019 & .161 & .011 & .117 & .907 \\
\hline & $\mathrm{DU}$ & -.126 & .146 & -.082 & -.866 & .388 \\
\hline
\end{tabular}

a. Dependent Variable: IR1

Figure 5 The statistical result of IR1

The results of the data processing show that the influence of the independent variable on the initial return of the first day was not found at all (Figure 5). This is consistent with the results of descriptive analyzes that have been carried out previously. Statistical results for IR1 condition show there is no Sig. (Significance) of each of the ROE, DER, BIRATE, DA, and DU variables that are more than 0.05 . A variable will be declared to have a significant effect on other variables if the significance value is less than 0.05 . 


\begin{tabular}{|c|c|c|c|c|c|c|}
\hline \multicolumn{7}{|c|}{ Coefficients ${ }^{x}$} \\
\hline \multirow[b]{2}{*}{ Made } & & \multicolumn{2}{|c|}{ Unstandardized Coefficients } & \multirow{2}{*}{$\begin{array}{c}\begin{array}{c}\text { Standardized } \\
\text { Coefficients }\end{array} \\
\text { Beta } \\
\end{array}$} & \multirow[b]{2}{*}{$t$} & \multirow[b]{2}{*}{ Siq. } \\
\hline & & B & Std. Error & & & \\
\hline 1 & (Constant) & 3.253 & .745 & & 4.367 & .000 \\
\hline & ROE & -.006 & .008 & -.071 & -.791 & .431 \\
\hline & DER & -.244 & .566 & -.038 & -.431 & .667 \\
\hline & BIRATE & -.398 & .108 & -.328 & -3.685 & .000 \\
\hline & DA & .282 & .416 & .060 & .677 & .500 \\
\hline & DU & -.653 & .378 & -.154 & -1.731 & .086 \\
\hline
\end{tabular}

a. Dependent Variable: IR?

Figure 6 The statistical result of IR7

As for conditions on the initial return of the seventh day, the 30th day or one month, and one year for the same and consistent results is the BI rate variable has a significant and negative effect on the initial return (Figures 6, 7, and 8). These results are also consistent with the previous scatterplot descriptive analysis for the initial return conditions of the seventh day, 30th day, and one year in which Table 1 shows the BI Rate variable is negatively related to the initial return.

\begin{tabular}{|c|c|c|c|c|c|c|}
\hline \multicolumn{7}{|c|}{ Coefficients } \\
\hline \multirow[b]{2}{*}{ Mads } & & \multicolumn{2}{|c|}{ Unstandardized Coefficients } & \multirow{2}{*}{$\begin{array}{c}\text { Standardized } \\
\text { Coefficients }\end{array}$} & \multirow[b]{2}{*}{$t$} & \multirow[b]{2}{*}{ Siq. } \\
\hline & & B & Std. Error & & & \\
\hline \multirow[t]{6}{*}{1} & (Constant) & 5.394 & 1.064 & & 5.067 & .000 \\
\hline & ROE & -.009 & .011 & -.075 & -.862 & .390 \\
\hline & DER & -.439 & .808 & -.047 & -.543 & .589 \\
\hline & BIRATE & -.666 & .154 & -.376 & -4.317 & .000 \\
\hline & $\mathrm{DA}$ & -.741 & .595 & -.108 & -1.245 & .216 \\
\hline & DU & -.952 & .540 & -.153 & -1.765 & .080 \\
\hline
\end{tabular}

a. Dependent Variable: IR30

Figure 7 The statistical result IR30

\begin{tabular}{|c|c|c|c|c|c|c|}
\hline \multicolumn{7}{|c|}{ Coefficients ${ }^{2}$} \\
\hline \multirow[b]{2}{*}{ Made } & & \multicolumn{2}{|c|}{ Unstandardized Coefficients } & \multirow{2}{*}{$\begin{array}{c}\begin{array}{c}\text { Standardized } \\
\text { Coefficients }\end{array} \\
\text { Beta }\end{array}$} & \multirow[b]{2}{*}{$t$} & \multirow[b]{2}{*}{ Sig. } \\
\hline & & $\mathrm{B}$ & Std. Error & & & \\
\hline \multirow[t]{6}{*}{1} & (Constant) & 7.550 & 1.807 & & 4.179 & .000 \\
\hline & $\mathrm{ROE}$ & -2.703 & 1.932 & -.129 & -1.399 & .165 \\
\hline & DER & .032 & .085 & .036 & .382 & .703 \\
\hline & BIRATE & -.939 & .285 & -.301 & -3.300 & .001 \\
\hline & $\mathrm{DA}$ & -1.302 & 1.116 & -.105 & -1.167 & .246 \\
\hline & DU & -1.222 & .985 & -.112 & -1.241 & .217 \\
\hline
\end{tabular}

a. Dependent Variable: IR1Y

Figure 8 The statistical result IR1Y 
Based on the statistical results on IR1, IR7, IR 30, and IR1Y, each observation period equation is as follows:

$$
\begin{aligned}
& \mathrm{IR}_{1}=0.357+0.000 \mathrm{ROE}+0.165 \mathrm{DER}-0.044 \mathrm{BIRATE}+0.019 \mathrm{DA}-0.126 \mathrm{DU}+\mathrm{e} \\
& \mathrm{IR}_{7}=3.253-0.006 \mathrm{ROE}-0.244 \mathrm{DER}-0.398 \mathrm{BIRATE}+0.282 \mathrm{DA}-0.653 \mathrm{DU}+\mathrm{e} \\
& (6) \mathrm{IR}_{30}=5.394-0.009 \mathrm{ROE}-0.439 \mathrm{DER}-0.666 \mathrm{BIRATE}-0.741 \mathrm{DA}- \\
& \begin{array}{l}
\text { 0.952DU }+\mathrm{e} \\
1.302 \mathrm{DA}-1.222 \mathrm{DU}+\mathrm{e} \quad(9)
\end{array}
\end{aligned}
$$

Note:

$\begin{array}{ll}\mathrm{IR}_{1} & \text { = Initial Return on the first day after IPO } \\ \mathrm{IR}_{7} & =\text { Initial Return on the seventh day after IPO } \\ \mathrm{IR}_{30} & \text { = Initial Return on the 30th day after IPO } \\ \mathrm{IR}_{1 \mathrm{y}} & =\text { Initial Return one year after IPO } \\ \mathrm{a} & =\text { Intercept } \\ \mathrm{b}_{\mathrm{i}}(\mathrm{i}=1,2,3 \ldots \mathrm{dst}) & =\text { coefficient Slope } \\ \mathrm{ROE} & =\text { Return on Equity } \\ \text { DER } & =\text { Debt to Equity Ratio } \\ \text { BIRATE } & =\text { Interest rate of BI } \\ \text { DA } & =\text { Dummy Auditor } \\ \text { DU } & =\text { Dummy Underwriter } \\ \text { e } & =\text { error }\end{array}$

Each R-Square value for each initial return condition is 2.1 percent for IR1, 13.6 percent for IR7, 17.6 percent for IR30, and 12.4 percent for IR1Y. The R-Square value shows how much percentage of all independent variables successfully explain the dependent variable. The largest R-Square value is the initial return condition thirty days after the IPO which is 17.6 percent, which means that the independent variable ROE, DER, BI rate, DA, and DU can explain the dependent variable as much as 17.6 percent, while the rest can be explained by other independent variables outside this research.

Of the five financial and non-financial variables used in this study, only one variable was found, the BI Rate, which had a partially significant negative effect on the initial return of shares of companies conducting an IPO on the IDX. This proves one hypothesis, the third hypothesis $\mathrm{H} 3$, which predicts that the BI Rate has a significant negative effect on the initial return that is true according to the results of the study. If the level of the BI Rate increases, the initial stock return will decrease. This is because the BI Rate is one of the references to see the movement of stock prices. The increase in the BI Rate is a negative signal to stock prices (Kewal 2012). Generally, people will tend to hold investments when the BI Rate is high because rising interest rates make the cost of company capital increase which has the potential to pose a risk to the company's profit.

While the other four variables, namely ROE, DER, DA, and DU were not found to have a significant partial effect on the initial return of shares of companies conducting IPOs on the first, seventh, thirty, and one year days. However, the four variables, together with the BI Rate variable simultaneously or jointly affect the initial return of shares of companies that conduct an IPO since the stock transaction on the seventh day to one year. 
In Benigno's (2016) study entitled Relationships between interest rate changes and stock returns: International evidence using a quantile-on-quantile approach is explained that according to financial theory, the influence of interest rates on stock prices occurs in several ways. First, interest rate movements have a direct effect on the discount rate used in the standard equity valuation model. Second, fluctuations in interest rates affect the cost of financing a company or issuer, especially if the company or issuer has a large debt burden, thus affecting the company's cash flow in the future. When the cost of financing the company increases or in other words, the responsibility of company costs increases, these conditions will have an impact on the value of company revenue or company performance.

Company achievement is the company's ability to manage the assets owned and specific resources to generate profits (Azhari 2016). Changes in stock prices are one indication of changes in company performance during a certain period. If a company's performance decreases as reflected by a decline in share prices, investors tend to be reluctant to invest their capital or will withdraw funds from a company. Third, variations in interest rates can also affect stock prices through a portfolio rebalancing strategy of investors. At this third point, an increase in interest rates, for example, will make investors shift their portfolios to interest-based investment products such as deposits and SBI rates. As a result, investors take action to sell so that there is a decline in stock prices and returns. Graham and Harvey (2001) state that interest rate risk is rated by US company managers as the second most relevant financial risk factor after credit risk.

From this explanation, it can be understood that the movement of interest rates cannot directly affect initial stock returns. Before finally affecting the value of the initial return significantly and negatively according to the results of this study, the interest rate first gives an impact on the issuer's stock price. When interest rates rise, the only direct effect for both issuers and investors as a public or individual is the increased cost of borrowing money from the Bank.

On the one hand, higher interest rates will benefit the financial institutions or lenders.

An increase in interest rates would drive up the cost of loaning, which indirectly will decrease the amount of money. The money can be spent by companies or individuals as investors to pay the debts to the banks or other financial institutions. To a certain extent, an increase in the burden of capital that is not accompanied by an increase in income with the same minimum percentage will result in a decrease in income, especially for companies. An increase in interest rates will limit the company's growth for the companies or issuers that use bank loans to carry out the business expansion. For issuers, where financial performance is presented to the public, this condition will make the share price decline. With lower expectations in growth and the company's future cash flow, investors will not get optimism for growth from the appreciation of share prices, thus making share ownership is less desirable.

Conversely, a decrease in interest rates is generally seen as a catalyst for economic growth for investors and companies or issuers. Companies mainly benefit from low capital costs when making bank loans for operational business needs or business expansion. Investors as individuals or communities will spend more money with lowinterest rates and will encourage the proportion of income on investment. The prospect of income that is not rigorous by the enormous capital costs will stimulate optimism for the company's performance in the future thus it encourages an increase in share prices which in turn promotes an increase in initial return. 


\section{Managerial Implication}

In this study, the BI Rate is the only non-financial variable in this study that was found to have a significant and negative influence on initial stock returns. For the company's management, conducting an initial public offering (IPO) is one of the main strategic initiatives in obtaining additional funding sources in addition to the company's capital. However, the strategy will continue to be managed so that it continues to provide added value to the company and other stakeholders. Based on the results of this study, the company management needs to pay attention to the movement of the BI Rate to estimate the impact of the movement of the value on the initial return value. This is important for company management because the initial return is one of the attractions for investors to invest. When the BI Rate falls, this condition is an opportunity for company management to get funds from investors through stock trading.

The downward BI Rate indicates that the money supply in the community is high, so in general the government will adopt a policy to withdraw money in circulation by raising interest rates. But in the same condition, the increased money supply in the community is an opportunity for cash capital for companies by holding an initial public offering (IPO). However, the phenomenon that often occurs after shares are traded in the secondary market is underpricing of shares, where the stock price on the stock exchange at the close of the first day is higher than the stock price when offered at the IPO. As a result of underpricing, investors will get an initial return.

Even though when the BI Rate goes down where according to the results of the initial return research it is calculated that it will increase and make the issuer unable to get the maximum acquisition of funds, it is not a condition that is detrimental to the company's management. This is explained as a strategy for the company management or the issuer. According to Gumanti and Alkaf (2011), underpricing when the initial public offering is a signal given by issuers to prospective investors on the quality of their companies. Good quality issuers are intentionally underpricing shares to obtain success every time they conduct an IPO offering or in the future. Also, another implication that issuers also expect from this signal is to reduce the level of underpricing at the time of the next share offering.

Thus, the managerial step that needs to be taken by the management of the company or issuer is to make an initial public offering when the BI Rate goes down with risk despite an underpricing condition. Welch and Ritter (2002) revealed the concept of signal theory in the phenomena of underpricing. Underpricing is stated as a mechanism of the company to indicate the investors about the quality of the company. Therefore, the companies that have a good quality intentionally underpricing shares so that the company will get the success of the sale of shares during the IPO and the subsequent stock offering.

While for investors, the condition of the BI Rate needs to be considered to analyze the benefits of the initial public offering. When the BI Rate falls, according to the results of the study, there is a probability of an increase in initial return that will be obtained from buying shares. Conversely, if the BI Rate arises, investors have the option to continue buying stocks with the probability of an initial return going down or deciding to keep money in a bank with a high return on interest rates and low risk or diversifying investment in other investment tools. Another alternative is that investors can use the services of stockbrokers to minimize the risk of loss in share purchases when there is an increase in the BI Rate. 


\section{Conclusion}

\section{Conclussion and Recommendation}

The results of this study indicate that the variable BI rate or interest rate affects the initial return negatively and significantly. When the value of the BI Rate increases, the initial return will decrease, and vice versa if the value of the BI Rate decreases, the initial return will increase. Aside from that, the ROE, DER, and dummy variable auditor's reputation and underwriter reputation were found not to influence initial return significantly. An increased initial return indicates that the condition of underpricing is increasing, or in other words, the relationship of initial return and underpricing is directly proportional.

Investors have an excellent opportunity to make an initial share purchase when the BI Rate decreases because it will benefit from an increase in initial return. When the value of the BI Rate rises, investors can diversify investments or use the services of stockbrokers to minimize the risk of loss in share purchases. For issuers, when the value of the BI Rate decreases where the cost of initial return will increase and the condition of underpricing is indicated to increase, it can be used as a strategy to attract investors and prove the quality of the company's performance. Then, at the time of the implementation of the next offer, it can attract more investors while reducing the level of underpricing.

\section{Recommendation}

Research on the factors that influence initial return on companies that conduct IPOs is very diverse. This research is limited to the analysis of two financial variables and one non-financial variable and two dummy variables. So for further study, another variable can be added such as company size, dummy variable type of company sector, and so on, given that the R-Square value generated in this study is small, indicating that there are still other variables outside the research that can affect the initial return. Descriptive analysis results in this study related to the behavior of initial return per sector also need to be further developed and statistically tested.

\section{References}

Azhari, D. F., Rahayu, S. M., Zahroh, Z. A. (2016). Pengaruh ROE, DER, TATO, dan PER terhadap harga saham perusahaan properti dan real estate yang go public di Bursa Efek Indonesia. Jurnal Administrasi Bisnis, 32(2), 1-5.

Benigno, A. M. (2016). Relationships Between Interest Rate Changes and Stock Returns: International Evidence Using A Quantile-On-Quantile Approach. Universidad Complutense de Madrid, Madrid.

Emilia, L. S., Roy, S. (2008). Faktor-Faktor yang Mempengaruhi Initial Return 1 Hari, 1 Bulan, dan Pengaruh Terhadap Return 1 Tahun Setelah IPO. Journal of Applied Finance and accounting, 1(1), 116-140.

Field, L.C., Dennis, P. S. (2004). IPO Underpricing and Outside Blockholdings. SSRN Electronic Journal, 10(2).

Graham, J. R., Harvey, C. R. (2001). The heory and practice of corporate finance: Evidence from the field. Journal of Financial Economics, 60(2), 187-243. 
Gumanti, T.A., Alkaf, N. (2011). Underpricing dalam Penawaran Saham Perdana dan Penawaran Saham Susulan. Jurnal Akuntansi dan Keuangan Indonesia, 8(1), 21-35.

Hanafi, M., Abdul, H. (2000). Analisis Laporan Keuangan. Yogyakarta, Indonesia: UPP AMP YKPN.

Hartono, J. (2013). Teori Portofolio dan Analisis Investasi. Yogyakarta, Indonesia: BPFE

Junaeni I., Rendi, A. (2013). Analisis Faktor-faktor yang mempengaruhi Tingkat Underpricing Saham pada Perusahaan yang melakukan Initial Public Offering di BEI. Jurnal Ilmiah WIDYA, 1(1), 52-59.

Kewal, S. S. (2012). Pengaruh Inflasi, suku Bunga, Kurs, dan Pertumbuhan PDB terhadap Indeks Harga Saham Gabungan. Jurnal Economia, 8(1), 53-64.

Li, M., Steven X. Z., Melissa, V. M. (2005). Underpricing, Share Retention, and The IPO Aftermarket Liquidity. International Journal of Managerial Finance, 1(2).

Pompian, M. M. (2006). Behavioral Finance and Wealth Management. New York, United States of America: John Wiley \& Sons, Inc.

Ratnasari, A., Gunasti, H. (2013). Analisis Pengaruh Informasi Keuangan, Non Keuangan serta Ekonomi Makro terhadap Underpricing pada Perusahaan ketika IPO. Jurnal Buletin Studi Ekonomi, 18, 85-97.

Risqi, I.A., Puji, H. (2013). Analisis Faktor-faktor yang mempengaruhi Underpricing ketika Initial Public Offering (IPO) di Bursa Efek Indonesia . Diponegoro Journal of Accounting, 2(3), 1-7.

Ritter, J. R.,Welch, I. (2002). A review of IPO activity, pricing and allocations. The Journal Of Finance, 57(4), 1795-1828.

Samsul, M. (2006). Pasar Modal dan Manajemen Portopolio. Jakarta, Indonesia: Erlangga.

Sawir, A. (2009). Analisa Kinerja Keuangan dan Perencanaan Keuangan Perusahaan. Jakarta, Indonesia: PT. Gramedia Pustaka Utama.

Usman, Marzuki. (1990). ABC Pasar Modal Indonesia. Jakarta, Indonesia: Ikatan Sarjana Ekonomi Indonesia. 